\title{
Some factors affecting the efficacy of oviduct tissue- conditioned medium for the culture of early bovine embryos
}

\author{
W. H. Eyestone*, J. M. Jones and N. L. First \\ Department of Meat and Animal Science, University of Wisconsin, Madison, \\ WI 53706, USA
}

\begin{abstract}
Summary. Oviduct tissue-conditioned medium was evaluated for the culture of IVMIVF bovine zygotes to the compact morula (cM) and blastocyst (BL) stages. Development was unaffected $(P>0.50)$ by freezing and thawing of conditioned medium: no. $\mathrm{cM}+\mathrm{BL} / \mathrm{no}$. cleaved ova obtained after culture in nonfrozen, frozen-thawed, and control treatments were $31 / 148(21 \%), 26 / 124(21 \%)$ and $5 / 86(6 \%)$, respectively. The greatest proportion of normal development was obtained after a conditioning period of $48 \mathrm{~h}(P<0.05)$ : no. of $\mathrm{cM}+\mathrm{BL} /$ no. cleaved ova in media conditioned for $5,24,48$ and $96 \mathrm{~h}$ were $23 / 114(20 \%), 38 / 112(34 \%), 43 / 115(37 \%)$ and $36 / 125(29 \%)$, respectively. Development declined with increasing dilutions of conditioned media $(P<0.005)$ : no. $\mathrm{cM}+\mathrm{BL} /$ no. cleaved ova for $100,75,50,25$ and $0 \%$ conditioned medium were $32 / 94(34 \%), 29 / 94(31 \%), 17 / 82(21 \%), 10 / 94(11 \%)$ and $11 / 73(15 \%)$, respectively. The oestrous cycle stage from which oviducal tissue was obtained did not affect development $(P>0 \cdot 75)$; no. $\mathrm{cM}+\mathrm{BL} /$ no. cleaved ova was $21 / 63(33 \%)$ at oestrus and $21 / 79(27 \%)$ in the luteal phase.
\end{abstract}

Ke I'words: embryo; blastocyst; in vitro; cattle; oviduct

\section{Introduction}

Early bovine embryos cultured in vitro fail to develop past the 8-16-cell stage in a variety of media (Wright \& Bondioli, 1981), including follicular fluid (Thibault, 1966), simple defined media (BMOC; McKenzie \& Kenney, 1973) and 'complex' media (Camous et al., 1984; Heyman et al., 1987; Eyestone \& First, 1989).

Recently, the co-culture of embryos with oviducal tissue (sheep: Rexroad \& Powell, 1986, 1988a, b; Gandolfi \& Moor, 1987; goat: Sakkas et al., 1989; cattle: Eyestone \& First, 1989) has been shown to permit cleavage past the 8-16-cell stage; indeed, compact morulae and blastocysts have been routinely obtained in these systems. In addition, medium conditioned by oviducal tissue was shown to be as effective as co-culture in supporting development from zygote to blastocyst, and to the hatched blastocyst stage (Eyestone \& First, 1989). Moreover, the transfer of morulae and blastocysts from conditioned medium to recipient cattle resulted in the birth of calves. Thus, medium conditioned by oviducal tissue supported normal development of early bovine embryos in vitro.

Conditioned medium presents several advantages over co-culture, namely, in eliminating the confounding presence of additional tissue and facilitating biochemical procedures in the search for soluble embryotrophic factors. The objective of the present study was to evaluate factors

*Present address: Department of Biochemistry, Gorlaeus Laboratory, Leiden University, 2333 CA Leiden, Netherlands. 
affecting the preparation, storage and use of oviduct-conditioned media, with the aim of optimizing conditions for embryo development.

A portion of this work has appeared in abstract form (Eyestone et al., 1990).

\section{Materials and Methods}

All incubations were performed in a humidified atmosphere of $5 \% \mathrm{CO}_{2}$ in air at $39^{\circ} \mathrm{C}$. Gametes and embryos were cultured in either $100 \mu \mathrm{l}$ (oocyte maturation) or $50 \mu \mathrm{l}$ (fertilization and embryo culture) droplets of medium under paraffin oil. Gentamycin sulphate $(25 \mu \mathrm{g} / \mathrm{ml})$ was included in all media.

Embryo source. Embryos were generated by in-vitro oocyte maturation and in-vitro fertilization according to methods described by Sirard et al. (1988). Intact cumulus-oocyte complexes were matured in TCM199+10\% heattreated foetal calf serum, supplemented with $5.0 \mu \mathrm{g}$ ovine luteinizing hormone (NIAMDD-oLH-024) $/ \mathrm{ml}, 0.5 \mu \mathrm{g}$ ovine follicle-stimulating hormone (NIAMDD-oFSH-015)/ml and $1.0 \mu \mathrm{g}$ oestradiol $-17 \beta / \mathrm{ml}$ ( 20 complexes/droplet). After $24 \mathrm{~h}$, cumulus-oocyte complexes with expanded cumulus masses were transferred to fertilization droplets, which consisted of Tyrode's medium, modified according to Bavister et al. ('TALP'; 1983) and supplemented with $2.0 \mu \mathrm{g}$ heparin/ml, and to which $5.0 \times 10^{4}$ swim-up separated spermatozoa were added. Cumulus oocyte complexes were removed from fertilization droplets after $18 \mathrm{~h}$, at which time cumulus cells were removed by gentle pipetting. At this point, 20-30 zygotes were fixed in ethanol:acetic acid ( $3: 1, \mathrm{v} / \mathrm{v})$, stained with $1 \%$ aceto-orcein (in $40 \%$ acetic acid), and examined by phase-contrast microscopy at $\times 400$ to determine fertilization frequency (percentage of ova with 2 pronuclei and a sperm tail).

Preparation of oviduct tissue-conditioned medium. Conditioned medium was prepared according to Eyestone \& First (1989). Oviducts were obtained at slaughter and transported to the laboratory on ice. Luminal tissue was harvested by gently scraping intact oviducts with a glass slide, washed 5 times in TALP (suplemented with $10 \mathrm{~mm}$ Hepes), then suspended in TCM199+10\% heat-treated foetal calf serum (M199+ FCS) to a tissue:medium ratio of 1:50. Media were conditioned in $50 \mathrm{ml}$ ' $\mathrm{T}$ ' flasks containing $5 \mathrm{ml}$ oviduct tissue suspension. Conditioned medium was prepared from the supernatant after centrifuging tissue suspensions at $13000 \mathrm{~g}$ for $10 \mathrm{~min}$. Media droplets, covered with paraffin oil, were incubated for $2 \mathrm{~h}$ to permit $\mathrm{pH}$ to equilibrate before adding zygotes.

Embryo culture. Zygotes were placed in culture droplets approximately $20 \mathrm{~h}$ after insemination. Initial cleavage ( $\geqslant 2$ cells) was assessed at $42 \mathrm{~h}$ after insemination. Media were not changed during the course of incubations. Criteria for normal development consisted of attainment of the compact morula (cM) or blastocyst stage (BL), or of the expanded blastocyst stage (xBL), by Day 6 or 9 after insemination, respectively. Development results are expressed as a function of cleaved ova.

Experiment 1. The cryostability of the embryotrophic property in conditioned medium was tested. Conditioned medium was prepared after $24-48 \mathrm{~h}$ incubation with oviducal tissue. A portion of the medium was frozen at $-20^{\circ} \mathrm{C}$. while another was held at room temperature. After $1 \mathrm{~h}$, the frozen portion was thawed and culture droplets prepared from both portions. Control droplets consisted of non-frozen M199 + FCS.

Experiment 2. The influence of length of conditioning period on embryo development was investigated. Media were conditioned for $5,24,48$ or $96 \mathrm{~h}$ and stored at $-70^{\circ} \mathrm{C}$ until use. All time treatments were represented in each replicate.

Experiment 3. The effect of dilution of conditioned medium on embryo development was examined. Conditioned medium, prepared as described in Exp. 1, was diluted with M199 + FCS to yield media containing 100, 75, 50, 25 and $0 \%$ conditioned medium.

Experiment 4. Embryo development in media conditioned by tissue from oviducts of cows at oestrus or in the luteal phase was compared. Oviducts were obtained from the abattoir and judged as 'oestrous' if they were accompanied by ovaries with regressing corpora lutea and follicles of at least $1.5 \mathrm{~cm}$ diameter, and cervices with copious amounts of clear mucus. Luteal-phase tracts were judged by the presence of large, healthy corpora lutea and the presence of scant quantities of opaque, viscous cervical mucus.

Statistics. Proportions were compared by $\chi^{2}$ analysis (Steel \& Torrie, 1960).

\section{Results}

\section{Experiment 1}

Development to the compact morula and blastocyst stages at Day 6 after insemination was similar between frozen-thawed and nonfrozen conditioned media $(P>0.75)$ but higher in either type of conditioned medium than in M199 + FCS $(P<0.005$; Table 1). 
Table 1. Effect of freezing and thawing of conditioned medium on development of cow zygotes to the compact morula $(\mathrm{cM})$ and blastocyst (BL) stages (4 replicates)

\begin{tabular}{lcc}
\hline Treatment & Initial cleavage $(\%)$ & $\mathrm{cM}+\mathrm{BL}^{2}(\%)$ \\
\hline Fresh & $148 / 177(84)$ & $3 \mathrm{l} / 148(21)^{\mathrm{a}}$ \\
Frozen-thawed* & $124 / 159(78)$ & $26 / 124(21)^{\mathrm{a}}$ \\
$\begin{array}{l}\text { Control (M199+ foetal calf } \\
\text { serum) }\end{array}$ & $86 / 126(69)$ & $5 / 86 \quad(6)^{\mathrm{b}}$ \\
\hline
\end{tabular}

$*-20 \mathrm{C}$ for $1 \mathrm{~h}$.

Development to $\mathrm{cM}+\mathrm{BL}$ did not differ between fresh and frozen-thawed treatments $(P>0.75) ; \chi^{2}=0.021$, d.f. $=1$.

a.bProportions differed $(P<0.005)$; fresh vs. control, $\chi^{2}=14.71$; frozenthawed vs. control, $\chi^{2}=8 \cdot 96 ;$ d.f. $=1$.

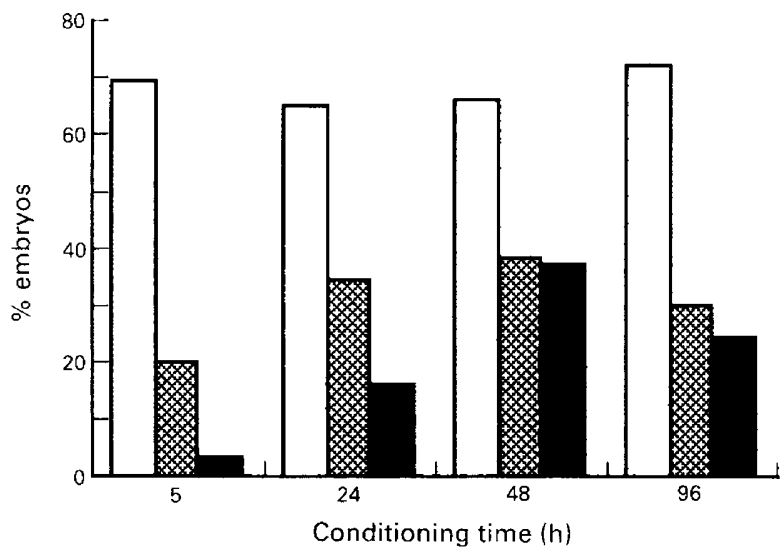

Fig. 1. Effect of conditioning time on cow embryo development in conditioned media. Zygotes were placed in conditioned media $20 \mathrm{~h}$ after insemination, examined for cleavage on Day 2 after insemination (open bars), for development to compact morula or blastocyst on Day 6 after insemination (cross-hatched bars) and expanded blastocyst on Day 9 after insemination (solid bars). Fertilization frequency: $77 \% ; n=679,4$ replicates.

\section{Experiment 2}

The yield of compact morulae and blastocysts on Day 6, and of expanded and hatched blastocysts on Day 9 after insemination, increased with increasing length of conditioning time up to $48 \mathrm{~h}$ $(P<0.05$, and $P<0.005$, respectively; Fig. 1). The yield of normally developed embryos was similar between 48 and $96 \mathrm{~h}$ of conditioning and was similar for embryos at Day $6(P>0 \cdot 10)$ and Day $9(P>0.25)$. Initial cleavage was unaffected by conditioning time $(P>0.975)$.

\section{Experiment 3}

The proportion of embryos that developed normally by Day 6 and Day 9 decreased with increasing dilutions of conditioned medium with M199 + FCS $(P<0.005$; Fig. 2), but initial cleavage was similar at all dilutions $(P>0.05)$.

\section{Experiment 4}

Development to compact morula or blastocyst stage was similar in medium conditioned by oviducal tissue from the oestrus or luteal phase $(P>0 \cdot 50)$. Development was higher in conditioned medium from either phase than in M199 + FCS $(P<0 \cdot 005$; Table 2). 


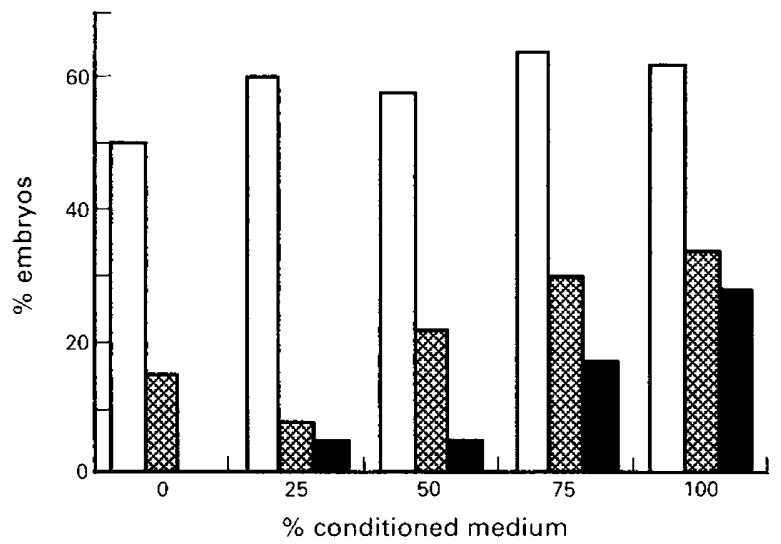

Fig. 2. Effect of dilution on cow embryo development in conditioned media. Zygotes were placed in conditioned media $20 \mathrm{~h}$ after insemination, examined for cleavage on Day 2 after insemination (open bars), for development to compact morula or blastocyst on Day 6 after insemination (cross-hatched bars) and expanded blastocyst on Day 9 after insemination (solid bars). Fertilization frequency: $69 \% ; n=735,4$ replicates.

Table 2. Cow embryo development in medium conditioned by oviduct tissue from the oestrous or luteal phases of the cycle ( 3 replicates)

\begin{tabular}{lcc}
\hline Cycle stage & Cleavage (\%) & $\mathrm{cM}+\mathrm{BL}(\%)$ \\
\hline Oestrous & $63 / 88(72)$ & $21 / 63(33)^{\mathrm{a}}$ \\
Luteal & $79 / 101(78)$ & $21 / 79(27)^{\mathrm{a}}$ \\
$\begin{array}{l}\text { Control (M199 + foetal calf } \\
\text { serum) }\end{array}$ & $68 / 88 \quad(77)$ & $5 / 68(7)^{\mathrm{b}}$ \\
\hline
\end{tabular}

Development to compact morula (cM) + blastocyst (BL) did not differ between oestrous and luteal treatments $(P>0 \cdot 50)$; $\chi^{2}=0 \cdot 477$, d.f. $=1$.

a, Proportions differed $(P<0.005)$; oestrous vs. control, $\chi^{2}=12 \cdot 29 ;$ luteal vs. control, $\chi^{2}=8 \cdot 01 ;$ d.f. $=1$.

\section{Discussion}

The results of this study confirm our previous observation (Eyestone \& First, 1989) that medium conditioned by oviducal tissue would support development from zygote to the expanded and hatched blastocyst stages. We have extended that work here to define several parameters that facilitate the preparation and optimize the performance of oviduct tissue-conditioned medium for embryo culture.

The ability of oviduct-conditioned medium to support embryo development remained stable through a single cycle of freezing and thawing (Table 1). This property alleviated the need to prepare new batches of conditioned medium for each experiment. It permitted single batches of conditioned medium to be stored frozen in small volumes so that the same batch could be used over several replicates and in a number of experiments. Although not specifically tested here, this approach should reduce potential variations in embryo development due to batch differences in conditioned medium.

Initial cleavage was unaffected by any of the treatments tested here, despite the fact that zygotes were transferred to culture treatments about $12 \mathrm{~h}$ before the first cleavage division (Eyestone \& 
First, 1988; Barnes \& Eyestone, 1990). Indeed, the rate of cleavage from the 1- to 8-cell stage may be similar in vitro and in vivo (Barnes \& Eyestone, 1990). Thus, the beneficial effect of oviducal tissue may not occur until around the 8-cell stage, at which point in-vitro cultured embryos encounter a block to development (Thibault, 1966; Camous et al., 1984; Heyman et al., 1987; Eyestone \& First, 1989).

The mechanism by which oviducal tissue imparted its beneficial effect to the medium is unclear. Possible explanations include the addition of embryotrophic substances to the medium, or the removal of embryo-suppressive components from the unconditioned M199 + FCS. No embryotrophin (i.e. a substance that specifically regulates development) has been identified in mammals. A protein of $M_{\mathrm{r}} 92000$ secreted by cultured sheep oviduct tissue has been shown to cross the zona pellucida and bind to sheep embryos (Gandolfi et al., 1989). Whether this protein, or any other protein, was responsible for the positive effect of oviduct co-culture on early embryo development in vitro was not determined in that study. Our data are consistent with the existence of a secretory factor, possibly a protein, which accumulates over time in culture (Fig. 1) and whose activity is reduced by dilution.

The beneficial effect of conditioned medium could also be mediated by the removal or modification of embryo-suppressive substances. For example, glucose and inorganic phosphate induced a 2-cell block in hamster embryos (Schini \& Bavister, 1988), pyruvate induced a 4-cell block in pigs (Davis \& Day, 1978) and hypoxanthine induced a 2-cell block in mice (Loutradis et al., 1987). In each case, the substances mentioned inhibited development at the precise stages where each species normally exhibits a block to in-vitro development.

Embryo development in conditioned medium was not affected by the oestrous cycle stage from which the oviduct tissue was obtained (Table 2). This result is consistent with those obtained after in-vivo culture in either rabbit (reviewed by Boland, 1984) or sheep (Willadsen, 1982; Moore et al., 1983; Eyestone et al., 1987) oviducts, in which development was similar in the oestrous and luteal phases, or in anoestrous and ovariectomized animals. The ability of the oviduct to support embryo development does not seem to vary during the oestrous cycle, despite cyclic changes in secretory activity and oviducal fluid composition (reviewed by Leese, 1988).

This research was supported by the College of Agricultural and Life Sciences, University of Wisconsin-Madison.

\section{References}

Barnes, F.L. \& Eyestone, W.H. (1990) Early cleavage and the maternal to zygotic transition in bovine embryos. Theriogenology 33, 141-152.

Bavister, B.D., Leibfried, M.L. \& Leiberman, G. (1983) Development of preimplantation embryos of the golden hamster in a defined culture medium. Biol. Reprod. 28, 235-247.

Boland, M.P. (1984) Use of the rabbit oviduct as a screening tool for the viability of mammalian eggs. Theriogenology 21, 126-137.

Camous, S., Heyman, Y., Meziou, W. \& Menezo, Y. (1984) Cleavage beyond the block stage and survival after transfer of early bovine embryos cultured with trophoblastic vesicles. J. Reprod. Fert. 72, 479-485.

Davis, D.L. \& Day, B.N. (1978) Cleavage and blastocyst formation by pig eggs in vitro. J. Anim. Sci. 46, 1043-1053.

Eyestone, W.H. \& First, N.L. (1989) Culture of early bovine embryos with oviductal tissue or in conditioned medium. $J$. Reprod. Fert. 85, 415-420.

Eyestone, W.H., Jones, J.M. \& First, N.L. (1990) Use of oviduct-tissue conditioned medium for culture of bovine zygotes to the blastocyst stage. Theriogeno$\log y 33,226$, abstr.

Eyestone, W.H. \& First, N.L. (1988) Cell cycle analysis of early bovine embryos. Theriogenology 29, 243, abstr.

Eyestone, W.H., Leibfried-Rutledge, M.L., Northey, D.L., Gilligan, B.G. \& First, N.L. (1987) Culture of one- and two-cell bovine embryos to the blastocyst stage in the ovine oviduct. Theriogenology 28, 1-7.

Gandolfi, F., Brevini, T.A.L., Richardson, L., Brown, C.R. \& Moor, R.M. (1989) Characterization of proteins secreted by sheep oviduct epithelial cells and their function in embryonic development. Development 106, 303-312.

Gandolfi, F. \& Moor, R.M. (1987) Stimulation of eary embryonic development in the sheep by co-culture with oviductal epithelial cells. J. Reprod. Fert. 81, 23-29.

Heyman, Y., Menezo, Y., Chesne, P., Camous, S. \& Gardinier, V. (1987) In vitro cleavage of bovine and ovine early embryos: improved development using coculture with trophoblastic vesicles. Theriogenology 27, 59-68. 
Leese, H.J. (1988) The formation and function of oviduct fluid $J$. Reprod. Fert. 82, 843-856.

Loutradis, D., John, D. \& Kiessling, A.A. (1987) Hypoxanthine causes a 2-cell block in random-bred mouse embryos. Biol. Reprod. 37, 311-316.

McKenzie, B.E. \& Kenney, R.M. (1973) In vitro culture of bovine embryos. Am. J. vet. Res. 34, 1271-1275.

Moore, N.W., Miller, B.G. Trappl, M.N. (1983) Transport and development of embryos transferred to the oviducts and uteri of entire and ovariectomized ewes. J. Reprod. Fert. 68, 1129-1135.

Rexroad, C.E., Jr \& Powell, A.M. (1986) Coculture of sheep ova and cells from sheep oviduct vesicles. Theriogenology 25, 187, abstr.

Rexroad, C.E., Jr \& Powell, A.M. (1988a) Coculture of ovine eggs with oviductal cells and trophoblastic vesicles. Theriogenology 29, 387-397.

Rexroad, C.E., Jr \& Powell, A.M. (1988b) Coculture of ovine ova with oviductal cells in medium 199. $J$. Anim. Sci. 66, 947-953.

Sakkas, D., Batt, P.A. \& Cameron, A.W.N. (1989) Development of preimplantation goat (Capra hircus) embryos in vivo and in vitro. J. Reprod. Fert. 87, 359-365.

Schini, S.A. \& Bavister, B.D. (1988) Two-cell block to development of cultured hamster embryos is caused by phosphate and glucose. Biol. Reprod. 39, 1183-1192.

Sirard, M.A., Parrish, J.J., Ware, C.B., LeibfrfiedRutledge, M.L. \& First, N.L. (1988) The culture of bovine oocytes to obtain developmentally competent embryos. Biol. Reprod. 39, 546-552.

Steel, R.G.D. \& Torrie, J.H. (1960) Principles and Procedures of Statistics. McGraw-Hill, New York.

Thibault, C. (1966) La culture in vitro de l'oeuf de vache. Annls Biol. anim. Biochim. Biophys. 6, 159-164.

Willadsen, S.M. (1982) Micromanipulation of embryos of the large domestic species. In Mammalian Egg Transfer, pp. 185-210. Ed. C. E. Adams. CRC Press. Boca Raton, FL.

Wright, R.W., Jr \& Bondioli, K.R. (1981) Aspects of in vitro fertilization and embryo culture in domestic animals. J. Anim. Sci. 53, 702-729.

Received 23 May 1990 